\title{
Evaluation of Different Lilium Hybrids under Climatic Conditions of Kashmir Valley
}

\author{
Nasir Hamid Masoodi ${ }^{1 *}$ and Sofi M Nayeem² \\ ${ }^{1}$ Division of Floriculture and Landscape Architecture SKUASTK, India \\ ${ }^{2}$ Division of Soil Science, India
}

Submission: May 08, 2018 Published: July 05, 2018

"Corresponding author: Nasir Hamid Masoodi, Division of Floriculture and Landscape Architecture SKUASTK, India, Email: nayeemnan1141@mail.com

\begin{abstract}
An experiment was carried out for evaluation of four Asiatic hybrid lilium varieties viz., four Asiatic hybrids Navona, Nello, Dailia and Blackout, three oriental hybrids viz. parrano, Tiber and Coca-D and two L.A. hybrids viz. Pedround and Yellow diamond. To assess their performance with respect to growth, flowering and bulb production at different altitudes of Kashmir Himalayas which includes Larnu District Anantnag (2133m amsl), Kandi Khas District Kupwara (1602m amsl) and Shalimar District Srinagar, $1591 \mathrm{~m}$ amsl? The genotype under study showed significant variation for different characters. The analysed data indicated that the variety in Asiatic hybribs (navona), in oriental (Parrano) and LA. (Pedround) recorded significantly maximum plant height $(56.7,75.2$ and $72.1 \mathrm{~cm})(53.2,71.3$ and 68.2$)$ and $(52.1,70.2$ and $66.6 \mathrm{~cm})$, Spike length $(41.7,60.2$ and $57.1 \mathrm{~cm})(38.2,56.3$ and $53.2 \mathrm{~cm})$ and $(37.1,55.2$ and $51.6 \mathrm{~cm})$, Spike Diameter $(1.5,1.5$ and $1.2 \mathrm{~cm})(1.3,1.2,1.2 \mathrm{~cm})$ and $(1.2,1.1$ and $1.0 \mathrm{~cm})$, fresh weight $(28.3,26.4$ and $20.8 \mathrm{gm})(26.6,21.2$ and $18.0 \mathrm{gm})$ and $(26.4,21.2$ and $18.0 \mathrm{gm})$, leaf area $\left(4.29,4.10 \mathrm{and} 3.26 \mathrm{~cm}^{2}\right)$ $\left(4.25,3.28\right.$ and $\left.3.24 \mathrm{~cm}^{2}\right)$ and $\left(4.21,3.20\right.$ and $\left.3.22 \mathrm{~cm}^{2}\right)$ and leaf area index $(0.715,0.68$ and 0.54$)(0.7,0.54$ and 0.54$)$ and $(0.7,0.54$ and 0.54$)$ at Larnoo, Kupwara and Shalimar among all the hybrid lilies. The hybrids also showed significant variation for flower parameters in which Asiatic hybrid (Navona), oriental hybrid (parrano) and L.A. hybrid (pedround) shows best results.
\end{abstract}

Keywords: Asiatic; Oriental; Evaluation; Significant; Plant height; Spike length

\section{Introduction}

Lilium is one among the important bulbous plants which is widely acclaimed for its use as cut flowers and pot plants. Lilium has been admired for its aesthetic beauty and has been depicted as a symbol of purity and regality. Genus Lilium belongs to family Liliaceae and is native to the Northern Hemisphere and geographically distributed over China (major centre of lily distribution in the world with 46 species and 18 varieties accounting for $50 \%$ of the total world [1], Japan, Siberia, South Canada and extends up to Florida (USA). In India, Lilium are found growing naturally in Nilgiri Hills and Himalayan regions [2].

Lilium are generally classified on the basis of their origin, form and position of flowers into nine divisions: Asiatic hybrids (group), Martagon hybrids (group 2), Candidum hybrids (group 3), American hybrids (group 4), Longiflorum hybrids (group 5), Trumpet-shaped and Aurelian hybrids (group 6), Oriental hybrids (group 7), various hybrids (group 8) and True species (group 9) [3]. About 100 species of genus Lilium have been reported. However lilies forced as cutflowers and potted plants are Lilium longiflorum, LA-hybrids, Asiatic hybrids and Oriental hybrids [4]. LA-hybrids were introduced in 1992 through cross between Longiflorum lilies (Lilium longiflorum) and Asiatic hybrids. The Longiflorum traits produce more of a trumpet shape and provide a longer vaselife. The Asiatic traits are responsible for the warmer colours and the upright calyx which causes the flower heads to face upward. The LA-hybrids bloom from mid-summer to late summer and may include colours like red, orange, yellow, violet and pink. Hybrid lilies are exceptionally useful as cut flowers and pot plants [5]. Many lilies also produce a charming effect when planted in front of shrubs in the garden; in large beds or borders lilies produce a showy display [2].

Lilium is the most spectacular and attractive bulbous flower. Lilium ranks 4th among the cut flowers in the world and lily bulb production in the Netherlands soared consistently 
during the second half of the 20th century, from about 100 ha in 1966 to over 3000 ha in 1993 [6]. Lilium ranks fourth among the top ten cut flowers in the global flower market upto 2005 [7]. The Netherlands, Japan and U.S.A. (Oregon) are the prime producers of both cutflowers and bulbs. On the eve of Easter, Lilium longiflorum popularity reaches peak heights in Japan and U.S.A. The commercial cultivation of Lilium in India [8] has been restricted to the states; Tamil Nadu, Kerala, Karnataka, Himachal Pradesh, Uttar Pradesh and Maharashtra.

Lilies are propagated sexually by seeds or asexually by natural formation of daughter bulbs, by axillary bulblets developed in the axils of leaves, stem bulblets formed underground or above ground and through scales. Micropropagation has also been a successful method for large-scale multiplication. Various plant parts like bulb scales, stem apices, apical meristems, floral organs, cotyledons etc., have been used for this purpose [2]. Scale propagation is widely used method for Lilium multiplication; however, the commercial size bulbs are obtained in 3-4 years [10]. Propagation through scales is a rapid means of multiplication, particularly in cultivars that do not produce stem bulbils [2].

A lot of work nhas been done previously on scale propagation of Lilium and it has been found that outer and middle scales produce more bulblets with greater weight as compared to inner ones $[11,12]$. Earlier a large number of substrates like cocopeat, vermiculite and sawdust $[9,13]$ have been used for lilium propagation which are costly and not available everywhere. Various types of forest soils and sawdust are easily available with the flower growers of Himachal Pradesh. Moreover, the spent mushroom compost is a useless waste product for mushroom industry. But the efficacy of these media has not yet been evaluated for lilium propagation.

\section{Material and Methods}

The present investigations "Evaluation of different Lilium hybrids under climatic conditions of Kashmir Valley" were carried out at the different locations of Kashmir Himalayas including Department of Floriculture and landscape Architecture SKUAST- Kashmir. The outline of the methodologies adopted for evaluating the Evaluation of different Lilium hybrids for vegetative parameters under open field conditions are as follows. Four Asiatic hybrids Navona, Nello, Dailia and Blackout, three oriental hybrids viz. parrano, Tiber and Coca-D and two L.A. hybrids viz. Pedround and Yellow diamond were screened for various vegetative and floral characters under the local agro climatic condition. Before planting soil testing was carried out and soil was prepared as per the requirement of Lilium crop. Nano silver was used for soil sterilisation and Nano gel and Nano char were incorporated in soil for soil moisture conservation. Besides this incorporation of well rotten FYM and fertilizers was ensured at the time of soil preparation. Altitudes of study for bulb production include Shalimar District Srinagar (1591m amsl), Larnu District Anantnag (2133m amsl), and Kandi Khas District Kupwara (1602m amsl). Observation on different parameters of vegetative growth and flowering characters were recorded. The mean values of the recorded data on various parameters were subjected to statistically analysis and presented in Table 1-6.

Table 1: Evaluation of different Lilium hybrids for vegetative parameters under open field conditions at Larnu District Anantnag (2133m amsl).

\begin{tabular}{|c|c|c|c|c|c|c|c|}
\hline & $\begin{array}{l}\text { Plant Height } \\
\text { (cm) }\end{array}$ & $\begin{array}{c}\text { Spike Length } \\
(\mathrm{cm})\end{array}$ & $\begin{array}{c}\text { Spike } \\
\text { Diameter }(\mathrm{cm})\end{array}$ & $\begin{array}{c}\text { Fresh Weight } \\
\text { (gm) }\end{array}$ & $\begin{array}{c}\text { Leaf Area } \\
\left(\mathrm{cm}^{2}\right)\end{array}$ & $\begin{array}{l}\text { Leaf Area } \\
\text { Index }\end{array}$ & $\begin{array}{c}\text { Relative } \\
\text { Growth Rate }\end{array}$ \\
\hline \multicolumn{8}{|c|}{ Asiatic Hybrids } \\
\hline Navona & 56.7 & 41.7 & 1.5 & 28.3 & 4.29 & 0.715 & 0.0043 \\
\hline Nello & 79.1 & 64.8 & 1.3 & 18 & 4.23 & 0.7 & 0.0242 \\
\hline Dailia & 75.4 & 60.4 & 1.4 & 21.4 & 4.28 & 0.71 & 0.0147 \\
\hline Blackout & 88.1 & 73.1 & 1.4 & 21.3 & 3.48 & 0.58 & 0.016 \\
\hline C.D(0.05) & 3.5 & 4.2 & 0.01 & 3.1 & 0.03 & 0.02 & 0.0015 \\
\hline \multicolumn{8}{|c|}{ Oriental Hybrids } \\
\hline Parrano & 75.2 & 60.2 & 1.5 & 26.4 & 4.1 & 0.68 & 0.0098 \\
\hline Tiber & 59.6 & 44.6 & 1.3 & 26.1 & 3.68 & 0.61 & 0.0181 \\
\hline concaD & 84.5 & 69.5 & 1.2 & 25.4 & 4.16 & 0.69 & 0.0138 \\
\hline C.D $(0.05)$ & 9.1 & 9.1 & 0.8 & 0.5 & 0.13 & 0.06 & 0.002 \\
\hline \multicolumn{8}{|c|}{ L.A. Hybrids } \\
\hline Pedround & 72.1 & 57.1 & 1.2 & 20.8 & 3.26 & 0.54 & 0.0143 \\
\hline Yellow Diamond & 77.2 & 62.2 & 1.5 & 24.4 & 4.22 & 0.7 & 0.0365 \\
\hline C.D $(0.05)$ & 4.9 & 4.9 & 0.01 & 3.4 & 0.94 & 0.14 & 0.002 \\
\hline
\end{tabular}




\section{Agricultural Research \& Technology: Open Access Journal}

Table 2: Evaluation of different Lilium hybrids for vegetative parameters under open field conditions at Kandi Khas District Kupwara (1602m amsl).

\begin{tabular}{|c|c|c|c|c|c|c|c|}
\hline & $\begin{array}{l}\text { Plant Height } \\
\text { (cm) }\end{array}$ & $\begin{array}{l}\text { Spike Length } \\
\text { (cm) }\end{array}$ & $\begin{array}{c}\text { Spike } \\
\text { Diameter }(\mathrm{cm})\end{array}$ & $\begin{array}{c}\text { Fresh Weight } \\
\text { (gm) }\end{array}$ & $\begin{array}{c}\text { Leaf Area } \\
\left(\mathrm{cm}^{2}\right)\end{array}$ & $\begin{array}{l}\text { Leaf Area } \\
\text { Index }\end{array}$ & $\begin{array}{c}\text { Relative } \\
\text { Growth Rate }\end{array}$ \\
\hline \multicolumn{8}{|c|}{ Asiatic Hybrids } \\
\hline Navona & 53.2 & 38.2 & 1.3 & 26.6 & 4.25 & 0.7 & 0.0044 \\
\hline Nello & 75.4 & 60.4 & 1.2 & 14 & 4.21 & 0.7 & 0.0248 \\
\hline Dailia & 56.6 & 41.6 & 1.2 & 17 & 3.36 & 0.56 & 0.0151 \\
\hline Blackout & 85.1 & 70.1 & 1.1 & 21.2 & 3.42 & 0.57 & 0.0164 \\
\hline C.D(0.05) & 3.2 & 3 & 0.08 & 2.8 & 0.04 & 0.12 & 0.011 \\
\hline \multicolumn{8}{|c|}{ Oriental Hybrids } \\
\hline Parrano & 71.3 & 56.3 & 1.2 & 21.2 & 3.28 & 0.54 & 0.0101 \\
\hline Tiber & 56.2 & 41.2 & 1.1 & 23.2 & 3.66 & 0.61 & 0.0185 \\
\hline concaD & 80.4 & 65.4 & 1 & 20.2 & 3.6 & 0.6 & 0.0141 \\
\hline C.D(0.05) & 8.8 & 8.7 & 0.1 & 2.6 & 0.58 & 0.5 & 0.002 \\
\hline \multicolumn{8}{|c|}{ L.A. Hybrids } \\
\hline Pedround & 68.2 & 53.2 & 1.1 & 18 & 3.24 & 0.54 & 0.0146 \\
\hline Yellow Diamond & 74.3 & 59.3 & 1 & 20.2 & 4.1 & 0.68 & 0.0375 \\
\hline C.D(0.05) & 5.9 & 5.8 & 0.08 & 2 & 0.83 & 0.12 & 0.0021 \\
\hline
\end{tabular}

Table 3: Evaluation of different Lilium hybrids for vegetative growth parameters under open field conditions at Shalimar District Srinagar (1591m amsl).

\begin{tabular}{|c|c|c|c|c|c|c|c|}
\hline & $\begin{array}{l}\text { Plant Height } \\
\text { (cm) }\end{array}$ & $\begin{array}{l}\text { Spike Length } \\
\text { (cm) }\end{array}$ & $\begin{array}{c}\text { Spike } \\
\text { Diameter }(\mathrm{cm})\end{array}$ & $\begin{array}{c}\text { Fresh Weight } \\
\text { (gm) }\end{array}$ & $\begin{array}{l}\text { Leaf Area } \\
\left(\mathrm{cm}^{2}\right)\end{array}$ & $\begin{array}{l}\text { Leaf Area } \\
\text { Index }\end{array}$ & $\begin{array}{c}\text { Relative } \\
\text { Growth Rate }\end{array}$ \\
\hline \multicolumn{8}{|c|}{ Asiatic Hubrids } \\
\hline Navona & 52.1 & 37.1 & 1.2 & 26.4 & 4.21 & 0.7 & 0.0078 \\
\hline Nello & 73.4 & 58.4 & 1.2 & 14 & 4.18 & 0.7 & 0.0308 \\
\hline Dailia & 55.2 & 40.2 & 1 & 17 & 3.36 & 0.56 & 0.0199 \\
\hline Blackout & 83.1 & 68.1 & 1.1 & 20 & 3.42 & 0.57 & 0.0213 \\
\hline C.D $(0.05)$ & 2.9 & 2.9 & 0.1 & 2.8 & 0.04 & 0.1 & 0.0012 \\
\hline \multicolumn{8}{|c|}{ Oriental Hybrids } \\
\hline Parrano & 70.2 & 55.2 & 1.1 & 21.2 & 3.28 & 0.54 & 0.0146 \\
\hline Tiber & 55.6 & 40.6 & 1.1 & 22.2 & 3.6 & 0.61 & 0.0228 \\
\hline concaD & 78.4 & 63.4 & 1 & 20.2 & 3.6 & 0.6 & 0.0186 \\
\hline C.D $(0.05)$ & 8 & 8 & 0.1 & 1.8 & 0.2 & 0.5 & 0.0038 \\
\hline \multicolumn{8}{|c|}{ L.A. Hybrids } \\
\hline Pedround & 66.6 & 51.6 & 1 & 18 & 3.22 & 0.54 & 0.0188 \\
\hline Yellow Diamond & 72.2 & 57.2 & 1 & 20.2 & 3.8 & 0.68 & 0.0456 \\
\hline C.D $(0.05)$ & 6.2 & 6.2 & 0.1 & 2 & 0.56 & 0.12 & 0.0266 \\
\hline
\end{tabular}

Table 4: Evaluation of different Lilium hybrids for flowering parameters under open field conditions at Larnu District Anantnag (2133m amsl).

\begin{tabular}{|c|c|c|c|c|c|c|}
\hline & Bud Length (cm) & $\begin{array}{c}\text { Number of Flower/ } \\
\text { Plant }\end{array}$ & $\begin{array}{c}\text { Flower Diameter } \\
\text { (cm) }\end{array}$ & $\begin{array}{c}\text { Inflorescence } \\
\text { Length (cm) }\end{array}$ & $\begin{array}{c}\text { Flowering Duration } \\
\text { in Days }\end{array}$ \\
\hline \multicolumn{7}{|c|}{ Asiatic Hybrids } \\
\hline Navona & 7 & 6.1 & 14 & 16.8 & 101.4 \\
\hline Nello & 7.6 & 4.6 & 15.8 & 17.2 & 9 \\
\hline Dailia & 8.5 & 4 & 20 & 17.3 & 132.7 \\
\hline Blackout & 9 & 5.8 & 19.5 & 20.1 & 132.9 \\
\hline
\end{tabular}


Agricultural Research \& Technology: Open Access Journal

\begin{tabular}{|c|c|c|c|c|c|}
\hline C.D $(0.05)$ & 0.5 & 0.04 & 0.03 & 1.4 & 1.6 \\
\hline \multicolumn{6}{|c|}{ Oriental Hybrids } \\
\hline Parrano & 7.4 & 7.6 & 14.9 & 17.5 & 101.2 \\
\hline Tiber & 8.2 & 4 & 20.3 & 16.1 & 132.9 \\
\hline concaD & 8.3 & 8 & 12.4 & 18.5 & 129.4 \\
\hline C.D(0.05) & 0.02 & 0.2 & 2.3 & 1.2 & 3.3 \\
\hline \multicolumn{6}{|c|}{ LA Hybrids } \\
\hline Pedround & 9.2 & 9 & 13.5 & 16 & 99.3 \\
\hline Yellow Diamond & 9.5 & 6.4 & 16.9 & 18.2 & 116.8 \\
\hline C.D (0.05) & 0.3 & 2.4 & 3.2 & 2 & 17.3 \\
\hline
\end{tabular}

Table 5: Evaluation of different Lilium hybrids for flowering parameters under open field conditions at Kandi Khas District Kupwara (1602m amsl).

\begin{tabular}{|c|c|c|c|c|c|}
\hline & Bud Length $(\mathrm{cm})$ & $\begin{array}{c}\text { Number of Flower/ } \\
\text { Plant }\end{array}$ & $\begin{array}{c}\text { Flower Diameter } \\
\text { (cm) }\end{array}$ & $\begin{array}{l}\text { Inflorescence } \\
\text { Length (cm) }\end{array}$ & $\begin{array}{c}\text { Flowering Duration } \\
\text { in Days }\end{array}$ \\
\hline \multicolumn{6}{|c|}{ Asiatic Hybrids } \\
\hline Navona & 6 & 3 & 12 & 16 & 94.1 \\
\hline Nello & 6.3 & 2 & 14.2 & 16.8 & 86.9 \\
\hline Dailia & 8.3 & 2 & 17.1 & 16.6 & 123.2 \\
\hline Blackout & 6 & 3 & 15.2 & 19.2 & 124.1 \\
\hline C.D $(0.05)$ & 0.1 & 0.8 & 1.9 & 0.6 & 0.9 \\
\hline \multicolumn{6}{|c|}{ Oriental Hybrids } \\
\hline Parrano & 6.4 & 2 & 18.3 & 16.5 & 97.4 \\
\hline Tiber & 8.1 & 3 & 18.4 & 15.4 & 130.4 \\
\hline concaD & 6.1 & 2 & 10.4 & 17.8 & 123 \\
\hline C.D(0.05) & 1.8 & 0.8 & 0.1 & 2.2 & 7.2 \\
\hline \multicolumn{6}{|c|}{ L.A. Hybrids } \\
\hline Pedround & 7.8 & 3 & 11.5 & 15 & 86.7 \\
\hline Yellow Diamond & 7 & 3 & 13 & 17.7 & 113.1 \\
\hline C.D(0.05) & 0.6 & 0.1 & 1.3 & 2.5 & 26.2 \\
\hline
\end{tabular}

Table 6: Evaluation of different Lilium hybrids for flowering parameters under open field conditions at Shalimar District Srinagar (1591m amsl).

\begin{tabular}{|c|c|c|c|c|c|}
\hline & Bud Length (cm) & $\begin{array}{c}\text { Number of Flower/ } \\
\text { Plant }\end{array}$ & $\begin{array}{c}\text { Flower Diameter } \\
(\mathrm{cm})\end{array}$ & $\begin{array}{l}\text { Inflorescence } \\
\text { Length }(\mathrm{cm})\end{array}$ & $\begin{array}{c}\text { Flowering Duration } \\
\text { in Days }\end{array}$ \\
\hline \multicolumn{6}{|c|}{ Asiatic Hybrids } \\
\hline Navona & 5.6 & 3 & 11.3 & 15.7 & 89.3 \\
\hline Nello & 6 & 2 & 13.4 & 16.4 & 86.7 \\
\hline Dailia & 8 & 2 & 16 & 16 & 121.1 \\
\hline Blackout & 5.8 & 3 & 14.2 & 19 & 123.6 \\
\hline \multicolumn{6}{|c|}{ Oriental Hybrids } \\
\hline C.D (0.05) & 1.8 & 0.8 & 2 & 0.2 & 2.3 \\
\hline Parrano & 6 & 2 & 17.3 & 16.1 & 91.1 \\
\hline Tiber & 7.6 & 3 & 17.4 & 15.1 & 123.4 \\
\hline concaD & 5.8 & 2 & 9.4 & 17.4 & 122 \\
\hline C.D (0.05) & 1.4 & 0.8 & $0.1^{\prime}$ & 0.8 & 1.2 \\
\hline \multicolumn{6}{|c|}{ L.A. Hybrids } \\
\hline Pedround & 7.4 & 3 & 10.4 & 14.8 & 86.2 \\
\hline Yellow Diamond & 6.6 & 3 & 12 & 17.3 & 112 \\
\hline C.D (0.05) & 1 & 0.01 & 2.2 & 3.2 & 25.4 \\
\hline
\end{tabular}




\section{Observational techniques and collection of experi- mental data}

Growth parameters: Observations on various growth parameters were recorded after one month of planting of bulbs.

Plant height: The height of the plant was recorded by measuring the length from the base to the highest point of growth (i.e., tip of the top most leaf) of the plant and average was worked out and expressed in centimetres.

Leaf length: The length of longest leaf in the plant was measured and expressed in centimetres.

Leaf width: The leaf used for measuring the length was also used for recording width. The widest part of the leaf.

\section{Observational techniques and collection of experi- mental data}

Growth parameters: Observations on various growth parameters were recorded after one month of planting of bulbs. Plant height, Spike length, Spike diameter, fresh weight, leaf area leaf area index and relative growth rate.

Leaf area: Leaf area was recorded with the help of leaf area meter by selecting five leaves randomly and equally from $10 \mathrm{~cm}$ middle length of selected plant. The readings were taken and expressed in square centimeters [14].

Floral parameters was also recorded which includes: Bud length $(\mathrm{cm})$, Number of flowers per plant, flower diameter $(\mathrm{cm})$, inflorescence length $(\mathrm{cm})$ and flowering duration (days).

\section{Results and Discussion}

The data pertaining to the growth parameters presented in Table 1-3 at different altitudes of Kashmir Himalayas. It is evident from the data that there is significant difference among different hybrid varieties of lilium. Asiatic hybribs (navona), oriental (Parrano) and LA. (Pedround) recorded significantly maximum plant height $(56.7,75.2$ and $72.1 \mathrm{~cm})(53.2,71.3$ and $68.2)$ and $(52.1,70.2$ and $66.6 \mathrm{~cm})$, Spike length $(41.7,60.2$ and $57.1 \mathrm{~cm})(38.2,56.3$ and $53.2 \mathrm{~cm})$ and $(37.1,55.2$ and $51.6 \mathrm{~cm})$, Spike Diameter $(1.5,1.5$ and $1.2 \mathrm{~cm})(1.3,1.2,1.2 \mathrm{~cm})$ and $(1.2$, 1.1 and $1.0 \mathrm{~cm})$, fresh weight $(28.3,26.4$ and $20.8 \mathrm{gm})(26.6,21.2$ and $18.0 \mathrm{gm})$ and $(26.4,21.2$ and $18.0 \mathrm{gm})$, leaf area $(4.29,4.10$ and $\left.3.26 \mathrm{~cm}^{2}\right)\left(4.25,3.28\right.$ and $\left.3.24 \mathrm{~cm}^{2}\right)$ and $(4.21,3.20$ and 3.22 $\left.\mathrm{cm}^{2}\right)$ and leaf area index $(0.715,0.68$ and 0.54$)(0.7,0.54$ and $0.54)$ and $(0.7,0.54$ and 0.54$)$ at Larnoo, Kupwara and Shalimar among all the hybrid lilies. The hybrids also showed significant variation for flower parameters at different locations Anantanag, Kupwara and Shalimar presented in Table 4-6. Bud length (cm) (7.0, 7.4 and 9.2), (6.0,6.3 and 6.4) and (5.6,6.0 and 7.4), Number of flowers per plant (6.1, 7.6 and 9.0), (3.0, 2.0 and 3.0) and (3.0, 2.0 and 3.0), (flower diameter (cm) (14.0, 14.9 and 13.5), (12.0, 18.4 and 11.5) and (11.3, 17.3 and 10.4), inflorescence length (cm) (16.8, 17.5 and 16.0), (16.0, 16.5 and 15.0) and (15.7, 16.1 and 14.8) and flowering duration (days) (101.4, 101.2 and 99.3), 94.1, 97.4 and 86.7) and (89.3, 91.1 and 86.2).

In Anantanag, Kupwara and Shalimar Asiatic hybrid (Navona), oriental hybrid (parrano) and L.A. hybrid (pedround) shows best results.

\section{Conclusion}

Despite the conditions during the growing period in the field, that were the same for all hybrids, the differences in performance observed in bulbs of the same hybrid clearly shows the importance of the sites of production in relation to the agroclimatic conditions, mainly temperature and how it affects the growth and flower development. Also, the dry temperate regions were suitable for plant growth and bulb development lilies.

\section{References}

1. Zhao XY, Chen XL, Wang SD (1996) Studies on germplasm of wild lilies in Quingling and Bash mountains. Acta University Voreali-Occident 18(4): 80-84.

2. Bose TK, Yadav LP (1998) Lilium. In: Commercial flowers. Naya Udhyog, Calcutta, India, p. 789.

3. De Jong PC (1972) De taxonomic van het geslacht Lilium. Rep 95, Wageningen, Netherlands.

4. Roh MS (1996) New production technology of Lilium- a review on propagation and forcing. Acta Horticulture 414: 219-228.

5. Bowser D (1986) Florist Reviews. 177: 29-32

6. Pizano M (2005) The changing lily scenes. Floriculture International 15(9): 10.

7. Raj D (2008) Global floriculture industry. In: Floriculture at glance. Kalyani Publishers. Ludhiana, p. 38.

8. Valliapan K (2005) Tamil Nadu - Flower bowl of India. Floriculture Today 10(2): 36-37.

9. Gupta YC, Dhiman SR, Kashyap B (2010) Effect of growing media and auxins on propagation of hybrid lilies through scaling. In: Abstract book, National Symposium on Lifestyle Floriculture: challenges and opportunities.

10. Park NB, Lee-Jong Suk, Roh MS (1996) Effect of temperature, scale positiand growth regulators on the bulblet formation and growth during scale propagation of Lilium. Acta Horticulture 414: 257-262.

11. Chung HJ, Choi CH, Park NB (1995) Effects of temperature, culturing media and auxin treatment on bulblet formation in scaling of lilies. Journal of the Korean Society for Horticultural Science 86(4): 567-573.

12. Sawwan J, Qrunfelh IM, Basher EA (2000) Effects of growth regulators on bulblet formation of Lilium longiflorum 'White American. Dirasat Agricultural Sciences 27(1): 20-25.

13. Sharma P, Sharma YD, Dhiman SR, Gupta YC (2007) Effect of growth regulators and growing media on propagation of Oriental lily hybrids through scaling. Journal of Ornamental Horticulture 10(3): 148-152.

14. Paramagoudar P (2010) Performance of dutch roses under polyhouse. MSc (Ag.) Thesis, University of Agricultural Sciences, Dharwad, Karnataka, India. 


\section{Your next submission with Juniper Publishers will reach you the below assets}

- Quality Editorial service

- Swift Peer Review

- Reprints availability

- E-prints Service

- Manuscript Podcast for convenient understanding

- Global attainment for your research

- Manuscript accessibility in different formats ( Pdf, E-pub, Full Text, Audio)

- Unceasing customer service

Track the below URL for one-step submission https://juniperpublishers.com/online-submission.php 